BIP: Jurna Bahasa Indonesia Prima,

Vol 3, No. 1, 2021, Maret 2021, pp.

\title{
PENINGKATAN KETERAMPILAN MENULIS KARYA ILMIAH SISWA KELAS XI IPS SMA NEGERI 1 BATANGHARI DENGAN PENDEKATAN KONTEKSTUAL KOMPONEN INKUIRI TAHUN PELAJARAN 2018/2019
}

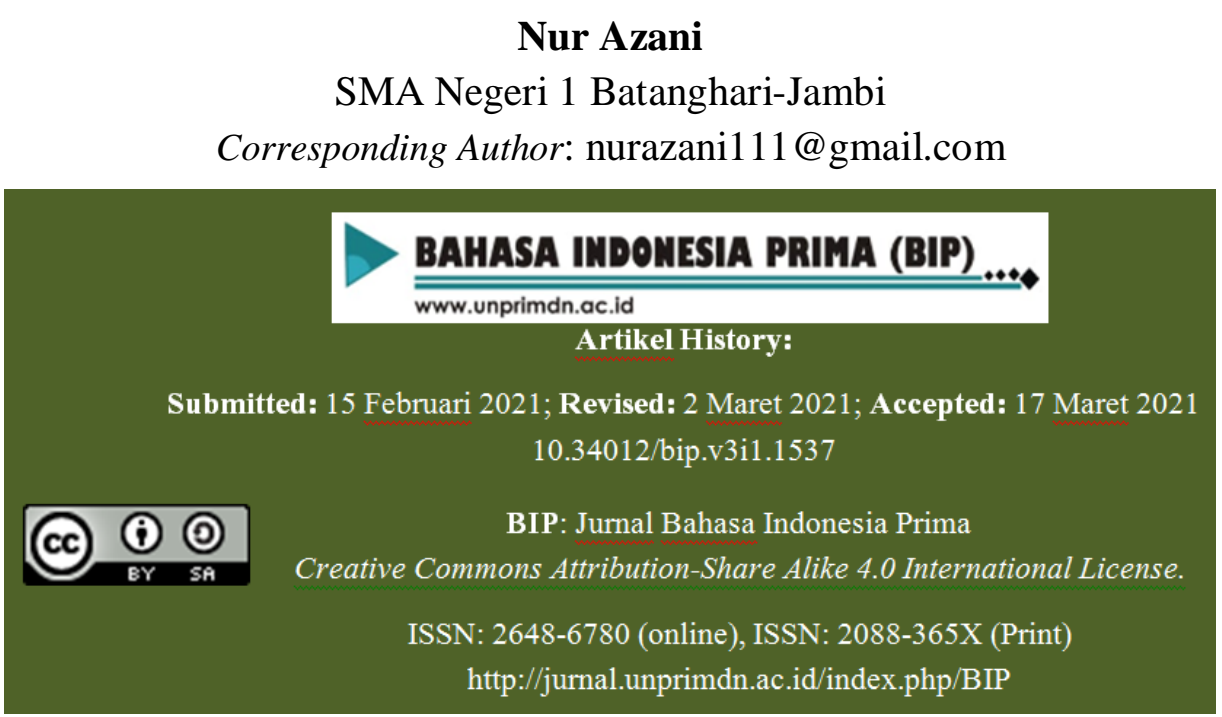

Abstrak-Keterampilan menulis karya ilmiah siswa kelas XI SMA Negeri 1 Batanghari masih rendah. Hal ini disebabkan kurangnya minat menulis dan proses pembelajaran menulis yang masih klasikal sehingga siswa kurang berminat terhadap pembelajaran menulis. Pendekatan kontekstual elemen inkuiri merupakan pendekatan pembelajaran yang mengajak siswa untuk menemukan pengetahuan baru secara mandiri dan kreatif sehingga siswa tidak hanya dikenalkan dengan teori, tetapi langsung pada konteksnya. Peningkatan keterampilan menulis karya ilmiah siswa kelas XI SMA Negeri 1 Batanghari dengan menggunakan pendekatan kontekstual elemen inkuiri dan mendeskripsikan peningkatan life skill siswa setelah kegiatan pembelajaran diterapkan dengan pendekatan kontekstual elemen inkuiri. Hasil penelitian menunjukkan model pengajaran dengan penerapan kontekstual komponen inkuiri dapat meningkatkan kualitas pembelajaran Bahas Indonesia materi Menulis Karya Ilmiah. Pembelajaran dengan penerapan pendekatan kontekstual komponen inkuiri memiliki dampak positif dalam meningkatkan prestasi belajar siswa yang ditandai dengan peningkatan ketuntasan belajar siswa dalam setiap siklus, yaitu siklus I (71\%), siklus II (80\%), siklus III $(94 \%)$.

Kata kunci: karya ilmiah, life skill, pendekatan kontekstual, inkuiri

\section{A. Pendahuluan}

Pembelajaran Bahasa Indonesia mengalami perkembangan yang pesat. Berbagai pendekatan, strategi, metode, dan media pembelajaran bahasa Indonesia yang inovatif dan variatif mulai diterapkan para guru bahasa Indonesia. Tujuan adanya perubahan pola embelajaran tersebut adalah dalam rangka pencapaian kompetensi siswa dalam bidang-bidang tertentu.

Penguasaan keterampilan dalam bidang bahasa Indonesia juga turut mendapatkan perhatian. Keterampilan berbahasa bukan lagi hanya untuk diketahui, melainkan untuk dikuasai oleh siswa. Keterampilan berbahasa memiliki empat komponen yang saling memengaruhi (Wagiran dan Doyin 
2005:1). Keempat keterampilan berbahasa tersebut adalah mendengarkan, berbicara, membaca, dan menulis (Tarigan 1982:1).

Kegiatan menulis memerlukan pengetahuan yang luas dan pola pikir yang logis. Pengetahuan yang luas tidak terlepas dari kegiatan membaca, maka kegiatan menulis harus diimbangi dengan kegiatan membaca. Keterampilan menulis menjadi suatu keterampilan yang penting untuk dikuasai siswa, karena budaya menulis adalah budayanya orang terpelajar (Winarmo 2002:3). Salah satu kegiatan menulis yang terdapat dalam kurikulum bahasa Indonesia SMA adalah menulis karya ilmiah. Keterampilan menulis karya ilmiah siswa SMA perlu ditingkatkan, karena berdasarkan pengamatan hasil karya tulis siswa biasanya lebih berorientasi pada banyak dan panjangnya karangan, bukan pada isi dan manfaat karangan (Doyin, dkk. 2002:v).

Dalam pelaksanaannya, komponen inkuiri dilaksanakan bersamaan dengan 6 komponen pendekatan kontekstual lainnya, yaitu konstruktivisme, bertanya, masyarakat belajar, pemodelan, refleksi, dan penilaian yang sebenarnya. Komponen inkuiri merupakan inti dari pembelajaran dengan menggunakan pendekatan kontekstual, karena inkuiri adalah kegiatan menemukan sebuah pengetahuan yang baru dengan cara menggali pengetahuan lama yang telah dibangun siswa melalui pertanyaan-pertanyaan, kemudian dapat dijawab dengan kegiatan inkuiri (menemukan) yang didiskusikan bersama kelompok belajar dan dikaitkan kembali dengan pemodelan, dan berakhir dengan menarik kesimpulan bersama guru dan penilaian karya dengan sebenarnya (Budiyati 2004:12).

Konsep life skill merupakan salah satu fokus analisis dalam pengembangan kurikulum pendidikan yang menekankan pada kecakapan hidup atau bekerja (Anwar 2004:20). Life skill atau kecakapan hidup adalah kecakapan yang dimiliki seseorang untuk berani menghadapi problema hidup dan kehidupan dengan wajar tanpa merasa tertekan, kemudian secara pro-aktif dan kreatif mencari serta menemukan solusi, sehingga akhirnya mampu mengatasinya (Depdiknas 2003 : 14).

Tujuan penelitian ini adalah sebagai berikut.

1. Mendeskripsikan peningkatan keterampilan menulis karya ilmiah siswa kelas XI IPS SMA Negeri 1 Batanghari yang diterapkan dengan pendekatan kontekstual komponen inkuiri.

2. Mendeskripsikan peningkatan life skill yang meliputi academic skill, personal skill, dan social skill siswa kelas XI IPS SMA Negeri 1 Batanghari setelah kegiatan pembelajaran menulis karya ilmiah diterapkan dengan pendekatan kontekstual komponen inkuiri.

Penelitian ini memiliki dua manfaat, yaitu:

\section{Manfaat Teoretis}

Secara teoretis penelitian ini dapat menjadi sumber referensi bagi penelitian penulisan karya ilmiah selanjutnya. Hasil yang akan dibahas dalam penelitian ini dapat menjadi gambaran secara konseptual terhadap guru untuk memberikan alternative bagi guru dalam melaksanakan kegiatan pembelajaran yang kreatif dan menyenangkan.

2. Manfaat Praktis

Secara praktis, penelitian ini bermanfaat bagi guru untuk menjadi alternative pendekatan bagi pembelajaran bahasa Indonesia yang 
efektif. Pembelajaran yang dilaksanakan dengan pendekatan kontekstual akan membuat siswa menjadi aktif, kreatif, dan mandiri. Pendekatan yang digunakan dalam penelitian ini dapat digunakan pada penelitian dan kegiatan pembelajaran yang lain, terutama penelitian pendidikan yang berorientasi pada peningkatan kemampuan akademik dan keterampilan siswa. Pihak sekolah dapat mengembangkan pendekatan kontekstual untuk digunakan pada semua mata pelajaran, namun harus disesuaikan dengan situasi dan kondisi sekolah.

\section{B. MetodePenelitian}

Penelitian ini merupakan penelitian tindakan (action search), yaitu dilakukan untuk memecahkan masalah pembelajaran di kelas. Penelitian ini juga termasuk penelitian deskriptif, sebab menggambarkan bagaimana suatu teknik pembelajaran diterapkan dan bagaimana hasil yang diinginkan dapat dicapai.

Penelitian bertempat di SMA Negeri 1 Batanghari. Waktu penelitian dilaksanakan pada bulan September-November 2018. Penelitian ini mengacu pada perbaikan pembelajaran yang berkesinambungan. Tahapan penelitian tindakan pada suatu siklus meliputi perencanaan atau pelaksanaan observasi dan refleksi. Siklus ini berlanjut dan akan dihentikan jika sesuai dengan kebutuhan dan dirasa sudah cukup.

Setiap siklus meliputi planning (rencana), action (tindakan), observation (pengamatan), dan reflection (refleksi). Langkah pada siklus berikutnya adalah perencanaan yang sudah direvisi, tindakan, pengamatan, dan refleksi. Sebelum masuk pada siklus I dilakukan tindakan pendahuluan yang berupa identifikasi permasalahan. Siklus spiral dari tahaptahap penelitian tindakan kelas dapat dilihat pada Gambar 1. Observasi dibagi dalam tiga siklus, yaitu siklus 1, 2, dan seterusnya, dimana masing siklus dikenai perlakuan yang sama (alur kegiatan yang sama) dan membahas satu sub pokok bahasan yang diakhiri dengan tes formatif di akhir masing putaran. Siklus ini berkelanjutan dan akan dihentikan jika sesuai dengan kebutuhan dan dirasa sudah cukup.

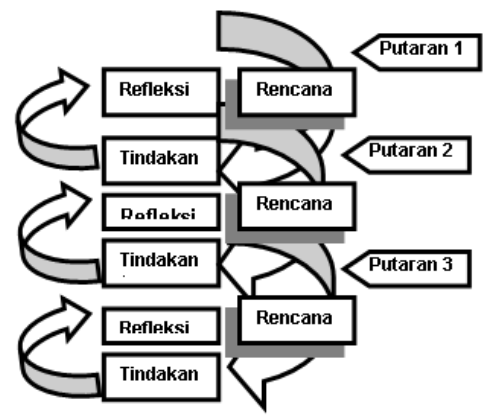

Gambar 1. Alur PTK

Alat pengumpul data dalam penelitian ini adalah tes buatan guru yang fungsinya adalah: (1) untuk menentukan seberapa baik siswa telah menguasai bahan pelajaran yang diberikan dalam waktu tertentu, (2) untuk menentukan apakah suatu tujuan telah tercapai, dan (3) untuk memperoleh suatu nilai (Arikunto, Suharsimi, 2002:149). Sedangkan tujuan dari tes adalah untuk mengetahui ketuntasan belajar siswa secara individual maupun secara klasikal. Di samping itu untuk mengetahui letak kesalahankesalahan yang dilakukan siswa sehingga dapat dilihat dimana kelemahannya, khususnya pada bagian mana TPK yang belum tercapai. Untuk memperkuat data yang dikumpulkan maka juga digunakan metode observasi (pengamatan) yang dilakukan oleh teman sejawat untuk mengetahui dan merekam aktivitas guru dan siswa dalam proses belajar mengajar. 
Dalam menganalisa data digunakan analisis data kuantitatif dan pada metode observasi digunakan data kualitatif. Cara penghitungan untuk mengetahui ketuntasan belajar siswa dalam proses belajar mengajar sebagai berikut.

1. Merekapitulasi hasil tes

2. Menghitung jumlah skor yang tercapai dan prosentasenya untuk masingmasing siswa dengan menggunakan rumus ketuntasan belajar seperti yang terdapat dalam buku petunjuk teknis penilaian yaitu siswa dikatakan tuntas secara individual jika mendapatkan nilai minimal 65, sedangkan secara klasikal dikatakan tuntas belajar jika jumlah siswa yang tuntas secara individu mencapai $85 \%$ yang telah mencapai daya serap lebih dari sama dengan $65 \%$.

3. Menganalisa hasil observasi yang dilakukan oleh guru sendiri selama kegiatan belajar mengajar berlangsung

\section{Hasil Penelitian}

Suatu pokok bahasan atau sub pokok bahasan dianggap tuntas secara klasikal jika siswa yang mendapat nilai 65 lebih dari atau sama dengan $85 \%$, sedangkan seorang siswa dinyatakan tuntas belajar pada pokok bahasan atau sub pokok bahasan tertentu jika mendapat nilai minimal 65.

\section{Siklus I}

\section{a.Tahap Perencanaan}

Pada tahap ini peneliti mempersiapkan perangkat pembelajaran yang terdiri dari rencana pelajaran 1 , soal tes formatif 1 , dan alat pengajaran yang mendukung. Selain itu dipersiapkan lembar observasi pengelolaan pembelajaran, dan lembar observasi aktivitas guru dan siswa.

b. Tahap Kegiatan dan Pelaksanaan

Pelaksanaan kegiatan belajar mengajar untuk siklus I dilaksanakan pada tanggal
15 Oktober 2018 di kelas XI IPS 5 dengan jumlah siswa 35 siswa. Dalam hal ini peneliti bertindak sebagai pengajar. Sebagai pengamat adalah guru Bahasa Indonesia lain dan wali kelas XI IPS 5. Adapun proses belajar mengajar mengacu pada rencana pelajaran yang telah dipersiapkan. Pengamatan (observasi) dilaksanakan bersamaan dengan pelaksanaan belajar mengajar. Pada akhir proses belajar mengajar siswa diberi tes formatif I dengan tujuan untuk mengetahui tingkat keberhasilan siswa dalam proses belajar mengajar. Hasil rekapitulasi tes formatif siswa pada Siklus I terdapat pada Tabel 1.

Tabel 1. Rekapitulasi Hasil Tes Formatif Siswa pada Siklus I

\begin{tabular}{|c|c|c|}
\hline No & Uraian & $\begin{array}{c}\text { Hasil } \\
\text { Siklus I }\end{array}$ \\
\hline 1 & $\begin{array}{l}\text { Nilai rata-rata tes } \\
\text { formatif }\end{array}$ & 71 \\
\hline 2 & $\begin{array}{l}\text { Jumlah siswa yang } \\
\text { tuntas belajar }\end{array}$ & 23 \\
\hline 3 & $\begin{array}{l}\text { Persentase } \\
\text { ketuntasan belajar }\end{array}$ & $65 \%$ \\
\hline
\end{tabular}

(Sumber: Hasil Analisis)

Dari tabel di atas dapat dijelaskan bahwa dengan menerapkan pembelajaran dengan metode kontekstual elemen inkuiri diperoleh nilai rata-rata prestasi belajar siswa adalah 71 dan ketuntasan belajar mencapai $71 \%$ atau ada 23 siswa dari 35 siswa sudah tuntas belajar. Hasil tersebut menunjukkan bahwa pada siklus pertama secara klasikal siswa belum tuntas belajar, karena siswa yang memperoleh nilai $\geq 65$ hanya sebesar $71 \%$ lebih kecil dari prosentase ketuntasan yang dikehendaki yaitu sebesar $85 \%$. Hal ini disebabkan karena siswa masih merasa baru dan belum mengerti apa yang dimaksudkan dan digunakan guru dengan menerapkan 
pembelajaran dengan pendekatan kontekstual elemen inkuiri.

c. Refleksi

Dalam pelaksanaan kegiatan belajar mengajar diperoleh informasi dari hasil pengamatan sebagai berikut:

1) Guru kurang maksimal dalam memotivasi siswa dan dalam menyampaikan tujuan pembelajaran

2) Guru kurang maksimal dalam pengelolaan waktu

3) Siswa kurang aktif selama pembelajaran berlangsung

d. Revisi

Pelaksanaan kegiatan belajar mengajar pada siklus I ini masih terdapat kekurangan, sehingga perlu adanya revisi untuk dilakukan pada siklus berikutnya.

1) Guru perlu lebih terampil dalam memotivasi siswa dan lebih jelas dalam menyampaikan tujuan pembelajaran. Dimana siswa diajak untuk terlibat langsung dalam setiap kegiatan yang akan dilakukan.

2) Guru perlu mendistribusikan waktu secara baik dengan menambahkan informasi-informasi yang dirasa perlu dan memberi catatan.

3) Guru harus lebih terampil dan bersemangat dalam memotivasi siswa sehingga siswa bisa lebih antusias.

\section{Siklus II}

\section{a. Tahap Perencanaan}

Pada tahap ini peneliti mempersiapkan perangkat pembelajaran yang terdiri dari rencana pelajaran 2, soal tes formatif 2 dan alat-alat pengajaran yang mendukung.

b. Tahap Kegiatan dan Pelaksanaan

Pelaksanaan kegiatan belajar mengajar untuk siklus II dilaksanakan pada tanggal 22 Oktober 2018 di kelas XI IPS 5 dengan jumlah siswa 35 siswa. Dalam hal ini peneliti bertindak sebagai pengajar.
Sebagai pengamat adalah guru Bahasa Indonesia lain dan wali kelas XI IPS 5. Adapun proses belajar mengajar mengacu pada rencana pelajaran dengan memperhatikan revisi pada siklus I, sehingga kesalahan atau kekurangan pada siklus I tidak terulang lagi pada siklus II. Pengamatan (observasi) dilaksanakan bersamaan dengan pelaksanaan belajar mengajar.Pada akhir proses belajar mengajar siswa diberi tes formatif II dengan tujuan untuk mengetahui tingkat keberhasilan siswa dalam proses belajar mengajar yang telah dilakukan. Instrumen yang digunakan adalah tes formatif II. Hasil rekapitulasi tes formatif siswa pada Siklus II terdapat pada Tabel 2.

Tabel 2. Rekapitulasi Hasil Tes Formatif Siswa pada Siklus II

\begin{tabular}{|l|l|c|}
\hline No & \multicolumn{1}{|c|}{ Uraian } & $\begin{array}{c}\text { Hasil } \\
\text { Siklus II }\end{array}$ \\
\hline 1 & $\begin{array}{l}\text { Nilai rata-rata tes } \\
\text { formatif } \\
\text { Jumlah siswa yang } \\
\text { tuntas belajar } \\
\text { Persentase } \\
\text { ketuntasan belajar }\end{array}$ & 28 \\
\hline
\end{tabular}

(Sumber: Hasil Analisis)

Dari tabel di atas diperoleh nilai ratarata prestasi belajar siswa adalah 75 dan ketuntasan belajar mencapai $80 \%$ atau ada 37 siswa dari 35 siswa sudah tuntas belajar. Hasil ini menunjukkan bahwa pada siklus II ini ketuntasan belajar secara klasikal telah mengalami peningkatan sedikit lebih baik dari siklus I. Adanya peningkatan kemampuan berbicara siswa ini karena setelah guru menginformasikan bahwa setiap akhir pelajaran akan selalu diadakan tes sehingga pada pertemuan berikutnya siswa lebih termotivasi untuk belajar. Selain itu siswa juga sudah mulai mengerti apa yang dimaksudkan dan diinginkan guru dengan menerapkan 
pembelajaran dengan pendekatan kontekstual elemen inkuiri.

c. Refleksi

Dalam pelaksanaan kegiatan belajar diperoleh informasi dari hasil pengamatan sebagai berikut.

1) Memotivasi siswa

2) Membimbing siswa merumuskan kesimpulan/menemukan konsep

3) Pengelolaan waktu

\section{d. Revisi Rancangan}

Pelaksanaan kegiatan belajar pada siklus II ini masih terdapat kekurangankekurangan. Maka perlu adanya revisi untuk dilaksanakan pada siklus II antara lain:

1) Guru dalam memotivasi siswa hendaknya dapat membuat siswa lebih termotivasi selama proses belajar mengajar berlangsung.

2) Guru harus lebih dekat dengan siswa sehingga tidak ada perasaan takut dalam diri siswa baik untuk mengemukakan pendapat atau bertanya.

3) Guru harus lebih sabar dalam membimbing siswa merumuskan kesimpulan/menemukan konsep.

4) Guru harus mendistribusikan waktu secara baik sehingga kegiatan pembelajaran dapat berjalan sesuai dengan yang diharapkan.

5) Guru sebaiknya menambah lebih banyak contoh soal dan memberi soal-soal latihan pada siswa untuk dikerjakan pada setiap kegiatan belajar mengajar.

\section{Siklus III}

a. Tahap perencanaan

Pada tahap ini peneliti mempersiapkan perangkat pembelajaran yang terdiri dari rencana pelajaran 3, soal tes formatif 3 dan alat-alat pengajaran yang mendukung.

b. Tahap kegiatan dan pengamatan
Pelaksanaan kegiatan belajar mengajar untuk siklus III dilaksanakan pada tanggal 29 Oktober 2018 di kelas XI IPS 5 dengan jumlah siswa 35 siswa. Dalam hal ini peneliti bertindak sebagai pengajar. Sebagai pengamat adalah guru Bahasa Indonesia lain dan wali kelas XI IPS 5. Adapun proses belajar mengajar mengacu pada rencana pelajaran dengan memperhatikan revisi pada siklus II, sehingga kesalahan atau kekurangan pada siklus II tidak terulang lagi pada siklus III. Pengamatan (observasi) dilaksanakan bersamaan dengan pelaksanaan belajar mengajar. Pada akhir proses belajar mengajar siswa diberi tes formatif III dengan tujuan untuk mengetahui tingkat keberhasilan siswa dalam proses belajar mengajar yang telah dilakukan. Instrumen yang digunakan adalah tes formatif III. Hasil rekapitulasi tes formatif siswa pada Siklus III terdapat pada Tabel3.

Tabel 3. Rekapitulasi Hasil Tes Formatif Siswa pada Siklus III

\begin{tabular}{|l|l|c|}
\hline No & \multicolumn{1}{|c|}{ Uraian } & $\begin{array}{c}\text { Hasil } \\
\text { Siklus III }\end{array}$ \\
\hline 1 & $\begin{array}{l}\text { Nilai rata-rata tes } \\
\text { formatif } \\
\text { Jumlah siswa yang } \\
\text { tuntas belajar } \\
\text { Persentase } \\
\text { ketuntasan belajar }\end{array}$ & 33 \\
\hline
\end{tabular}

(Sumber: Hasil Analisis)

Berdasarkan tabel di atas diperoleh nilai rata-rata tes formatif sebesar 79 dan dari 35 siswa telah tuntas sebanyak 33 siswa dan 2 siswa belum mencapai ketuntasan belajar. Maka secara klasikal ketuntasan belajar yang telah tercapai sebesar 94\% (termasuk kategori tuntas). Hasil pada siklus III ini mengalami peningkatan lebih baik dari siklus II. Adanya peningkatan kemampuan berbicara pada siklus III ini dipengaruhi 
oleh adanya peningkatan kemampuan guru dalam menerapkan pembelajaran dengan pendekatan kontekstual elemen inkuiri sehingga siswa menjadi lebih terbiasa dengan pembelajaran seperti ini sehingga siswa lebih mudah dalam memahami materi yang telah diberikan.

c. Refleksi

Pada tahap ini akan dikaji apa yang telah terlaksana dengan baik maupun yang masih kurang baik dalam proses belajar mengajar dengan penerapan pendekatan kontekstual elemen inkuiri. Dari data-data yang telah diperoleh dapat diuraikan sebagai berikut:

1) Selama proses belajar mengajar guru telah melaksanakan semua pembelajaran dengan baik. Meskipun ada beberapa aspek yang belum sempurna, tetapi prosentase pelaksanaannya untuk masing-masing aspek cukup besar.

2) Berdasarkan data hasil pengamatan diketahui bahwa siswa aktif selama proses belajar berlangsung.

3) Kekurangan pada siklus-siklus sebelumnya sudah mengalami perbaikan dan peningkatan sehingga menjadi lebih baik.

4) Kemampuan berbicara siswa pada siklus III mencapai ketuntasan.

d. Revisi Pelaksanaan

Pada siklus III guru telah menerapkan pendekatan kontekstual elemen inkuiri dengan baik dan dilihat dari aktivitas siswa serta kemampuan berbicara siswa pelaksanaan proses belajar mengajar sudah berjalan dengan baik. Maka tidak diperlukan revisi terlalu banyak, tetapi yang perlu diperhatikan untuk tindakan selanjutnya adalah memaksimalkan dan mempertahankan apa yang telah ada dengan tujuan agar pada pelaksanaan proses belajar mengajar selanjutnya penerapan pendekatan kontekstual elemen inkuiri dapat meningkatkan proses belajar mengajar sehingga tujuan pembelajaran dapat tercapai.

Perbandingan rekapitulasi hasil tes formatif siswa untuk setiap siklus disajikan pada Gambar 2.

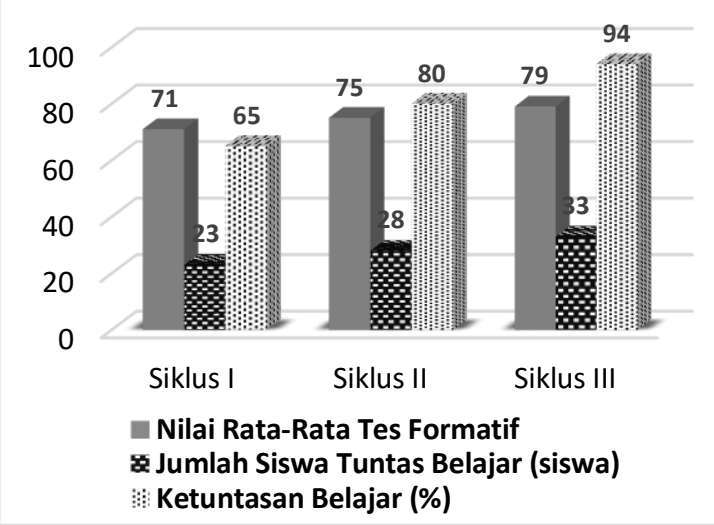

Gambar 2. Rekapitulasi Hasil Tes Formatif Siswa pada Setiap Siklus

Selain itu, penelitian ini membahas hal-hal berikut:

1. Ketuntasan Kemampuan Pemahaman Siswa

Melalui hasil penelitian ini menunjukkan bahwa pembelajaran dengan pendekatan kontekstual elemen inkuiri memiliki dampak positif dalam meningkatkan prestasi belajar siswa. Hal ini dapat dilihat dari semakin mantapnya pemahaman siswa terhadap materi yang disampaikan guru (ketuntasan belajar meningkat dari siklus I, II, dan III) yaitu masing-masing 71\%, 80\%, dan 94\%. Pada siklus III ketuntasan belajar siswa secara klasikal telah tercapai.

2. Kemampuan Guru dalam Mengelola Pembelajaran

Berdasarkan analisis data, diperoleh aktivitas siswa dalam proses belajar mengajar dengan menerapkan pendekatan kontekstual elemen inkuiri dalam setiap siklus mengalami peningkatan. Hal ini berdampak positif terhadap prestasi belajar siswa yaitu dapat ditunjukkan dengan 
meningkatnya nilai rata-rata siswa pada setiap siklus yang terus mengalami peningkatan.

3. Aktivitas Siswa Dalam Pembelajaran

Berdasarkan analisis data, diperoleh aktivitas siswa dalam proses pembelajaran Bahasa Indonesia dengan pendekatan kontekstual elemen inkuiri yang paling dominan adalah mendengarkan/ memperhatikan penjelasan guru, dan diskusi antar siswa/antara siswa dengan guru. Jadi dapat dikatakan bahwa aktivitas siswa dapat dikategorikan aktif. Sedangkan untuk aktivitas guru selama pembelajaran, telah melaksanakan langkah-langkah kegiatan belajar mengajar dengan menerapkan pendekatan konstekstual inkuiri dengan baik. Hal ini terlihat dari aktivitas guru membimbing dan mengamati siswa dalam menemukan konsep, menjelaskan materi yang sulit, memberi umpan balik/evaluasi/tanya jawab. Persentase untuk aktivitas di atas cukup besar.

\section{SIMPULAN}

Berdasarkan hasil penelitian yang telah dipaparkan selama tiga siklus, hasil seluruh pembahasan serta analisis yang telah dilakukan dapat disimpulkan sebagai berikut:

1. Model pengajaran dengan penerapan pendekatan kontekstual komponen inkuiri dapat meningkatkan kualitas pembelajaran Bahasa Indonesia materi Menulis Karya Ilmiah.

2. Pembelajaran dengan penerapan pendekatan kontekstual komponen inkuiri memiliki dampak positif dalam meningkatkan prestasi belajar siswa yang ditandai dengan peningkatan ketuntasan belajar siswa dalam setiap siklus, yaitu siklus I $(71 \%$,$) , siklus II$ (80\%), siklus III (94\%).
3. Pendekatan kontekstual komponen inkuiri dapat menjadikan siswa merasa dirinya mendapat perhatian dan kesempatan untuk menyampaikan pendapat, gagasan, ide dan pertanyaan.

4. Siswa dapat bekerja secara mandiri maupun kelompok, serta mampu mempertanggungjawabkan segala tugas individu maupun kelompok.

5. Penerapan pendekatan kontekstual elemen inkuiri mempunyai pengaruh positif, yaitu dapat meningkatkan kreatifitas belajar siswa.

Saran yang diberikan agar proses belajar mengajar Bahasa Indonesia lebih efektif dan lebih memberikan hasil yang optimal bagi siswa antara lain:

1. Untuk melaksanakan pendekatan kontekstual elemen inkuiri memerlukan persiapan yang cukup matang, sehingga guru harus mampu menentukan atau memilih topik yang benar-benar bisa diterapkan dengan pendekatan kontekstual elemen inkuiri dalam proses belajar mengajar sehingga diperoleh hasil yang optimal.

2. Dalam rangka meningkatkan prestasi belajar siswa, guru hendaknya lebih sering melatih siswa dengan berbagai metode pengajaran, walau dalam taraf yang sederhana, dimana siswa nantinya dapat menemukan pengetahuan baru, memperoleh konsep dan keterampilan, sehingga siswa berhasil atau mampu memecahkan masalah-masalah yang dihadapinya.

3. Perlu adanya penelitian yang lebih lanjut, karena hasil penelitian ini hanya dilakukan di kelas XI IPS 5 SMA Negeri 1 Batangharitahun pelajaran 2018/2019.

4. Untuk penelitian yang serupa hendaknya dilakukan perbaikan- 
BIP: Jurna Bahasa Indonesia Prima,

Vol 3, No. 1, 2021, Maret 2021, pp.

perbaikan agar diperoleh hasil yang lebih baik.

\section{DAFTAR PUSTAKA}

Anwar. 2004. Pendidikan Kecakapan Hidup (Life Skills Education) Konsep dan Aplikasinya. Bandung: Alfabeta.

Departemen Pendidikan Nasional. 2003. Pendekatan Kontekstual (Contextual Teaching and Learning (CTL)). Jakarta: Departemen Pendidikan Nasional.

Doyin, Mukh, Wagiran, Ida Zulaeha, Tommi Yuniawan. 2002. Bahasa Indonesia dalam Penulisan Karya Ilmiah. Semarang: Nusa Budaya.

Encep, Kusumah, Yeti Mulyati, Maman Suryaman. 2003. Menulis 2. Jakarta: Pusat Penerbitan Universitas Terbuka.

Hartono, Bambang. 2003. Kurikulum Berbasis Kompetensi Mata Pelajaran Bahasa Indonesia. Makalah disajikan dalam Workshop Implementasi Life Skill dan Budi Pekerti dalam Pembelajaran Bahasa Indonesia Berdasarkan Kurikulum Berbasis Kompetensi (4 s.d 11 Agustus) Dihimpun oleh Jurusan Bahasa dan Sastra Indonesia, Fakultas Bahasa dan Seni, Universitas Negeri Semarang.

Hastuti, Sri. 1996. Strategi Belajar Mengajar Bahasa Indonesia. Semarang: Departemen Pendidikan dan Kebudayaan.

Cahyanti. 2003. Mencoba, Belajar, dan Motivasi. Kompas Mahasiswa 71/XXVI. Hlm. 10.

Kurniawan, Khaerudin. 1998. Pembinaan

Kemahiran Menulis Mahasiswa Jurusan Pendidikan Bahasa dan Sastra Indonesia. Yogyakarta: IKIP Yogyakarta.

Nurhadi, Agus. 2003. Pembelajaran Kontekstual dan Penerapannya dalam Kurikulum Berbasis kompetensi. Malang: Universitas Negeri Malang.

Nursisto. 1999. Penuntun Mengarang. Yogyakarta: Adicipta Karya Nusa.

Subyantoro, Bambang Hartono. 2003. Pengembangan Kemampuan

Berbahasa (Pembelajaran

Keterampilan Mendengarkan, Berbicara, Membaca, dan Menulis). Makalah Disajikan pada Pelatihan Terintegrasi Berdasarkan Kurikulum Berbasis Komptensi.

Sudjana, Nana. 2001. Penelitian dan Penilaian Pendidikan. Bandung: Sinar Baru Algensindo.

Suriamiharja, Agus, Akhlan Husein, Nunuy Nursanah. 1996. Petunjuk Praktis Menulis. Jakarta: Departemen Pendidikan dan Kebudayaan.

Tarigan, Henry Guntur. 1982. Menulis Sebagai Suatu Keterampilan Berbahasa. Bandung: Angkasa.

Winarmo. 2002. Budaya Tulisan Versus Budaya Lisan. Tiara Bahasa

Wagiran, Mukh Doyin. 2005. Curah Gagasan Pengantar Penulisan Karya Ilmiah. Semarang: Rumah Indonesia Jurusan Bahasa dan Sastra Indonesia Universitas Negeri Semarang. 